\title{
El mono gramático: entre lenguaje y cuerpo
}

\author{
Helena Dunsmoor \\ University of Calgary \\ dunsmoor@ucalgary.ca
}

Resumen: Este ensayo analiza El mono gramático de Octavio Paz con el fin de demostrar que las conexiones, los espacios y los estados representados por la preposición entre constituyen una clave interpretativa importante. Los vínculos entre el lenguaje y el cuerpo son especialmente relevantes en El mono gramático. Al mismo tiempo, la conexión lenguaje-cuerpo tan presente en este libro es característica de todos los escritos de Octavio Paz. El entre es indicativo de la vivacidad de la obra poética paciana, así como del especial interés por lo que Paz llama la otredad. Paz cree que reconciliaciones momentáneas entre las contradicciones de la vida se hacen posibles a través del lenguaje poético y del amor físico. Hacia el final de este ensayo, se estudia la imagen del pliegue. Allí conectamos las figuraciones sexuales de Paz a una lectura más universal que se centra de nuevo en el eje entre el lenguaje y el cuerpo, tan crucial para El mono gramático y otras obras de Octavio Paz.

Aвstract: This essay analyses Octavio Paz's The Monkey Grammarian with the purpose of demonstrating that connections, spaces and states represented by the preposition between constitute an important interpretative key. The between that links language and the body is especially relevant in The Monkey Grammarian. At the same time, the language-body connection so present in this book is a feature of Octavio Paz's writing as a whole. The between is indicative of the vivacity of Paz's poetic works, as well as his particular interest in what he called otherness. Paz believed that momentary reconciliations between life's contradictions could come about through poetic language and bodily love. The image of the fold is taken up toward the end of this essay. Here we connect Paz's sexual imagery to a more universal reading that focuses again on the language-body junction so crucial to The Monkey Grammarian and other works by Octavio Paz.

Palabras ClaVe: Octavio Paz, El mono gramático, entre, lenguaje, cuerpo, erotismo, pliegue, otredad.

Keywords: Octavio Paz, The Monkey Grammarian, between, language, body, eroticism, fold, otherness. 
La sabiduría no está ni en la fijeza ni en el cambio, sino en la dialéctica entre ellos.

Octavio Paz, El mono gramático

Reflexionar sobre esta frase, que aparece temprano en El mono gramático, es vislumbrar una versión concentrada del libro entero. ${ }^{1}$ Digo bien una versión, pues se podrían expresar otras dinámicas igualmente representativas de la obra al reemplazar las palabras 'fijeza' y 'cambio' por 'destrucción' y 'renovación', 'dentro' y 'fuera de', o 'unión' y 'escisión'. A pesar de la gran diferencia significativa entre las varias parejas de antónimos, cuando dividimos la realidad en cualquier dualidad, nos basamos en un modelo de organización cuyos términos Octavio Paz describe, en Conjunciones y disyunciones, como: "[no] inteligibles sino en relación y no aisladamente considerados" (1969: 44). No debemos pasar por alto la dialéctica que Paz indica entre las voces supuestamente opuestas.

La preposición entre conecta en un nivel gramatical al mismo tiempo que hace resaltar la función primordial del mismo entre como un estado y un espacio. En toda la obra de Octavio Paz y en El mono gramático en particular, el entre enmarca la experiencia del ser humano y de ahí, constituye una poética vital en el corpus de nuestro autor. En un sentido concreto, entre es una representación de la experiencia humana por excelencia, dado que entre nacer y morir, se vive. Para Paz, no parece haber mucha distinción entre vivir y poetizar. Como él expresa en una entrevista, el lenguaje que refleja la experiencia poética es el corazón de la vida: "pour moi aussi la poésie est le noyeau secret de la véritable vie. Et la vie, ce n'est pas dans l'au-delà mais ici-même. Cette affirmation de l'Instant qui se trouve surtout dans l'expérience de l'amour, dans l'expérience poétique et dans l'expérience de la révolte, a été pour moi la grande leçon du Surrealisme" (citado en Blandin: 56-57). ${ }^{2}$

Ahora que Paz equipara la experiencia poética con la del amor, se infiere que el lenguaje y el cuerpo están en la base de todo acto creativo y

\footnotetext{
${ }^{1}$ En 1972 el libro se edita por primera vez traducido al francés por Claude Esteban en la colección Les sentiers de la création, dirigida por Albert Skira. Dos años más tarde, la Editorial Seix Barral publica el texto original en castellano.

2 “[...] para mí también la poesía es el núcleo secreto de la verdadera vida. Y la vida no está en el más allá, sino aquí mismo. Esta declaración del Instante que se produce principalmente en la experiencia del amor, en la experiencia poética y en la experiencia de la revuelta, fue para mí la gran lección del surrealismo" (mi traducción).
} 
amoroso para el poeta mexicano. No se vive sin cuerpo como tampoco se poetizan las experiencias de ser, estar y amar sin el lenguaje. Clarifico que el amor en la obra paciana es sensual: el yo rinde culto al cuerpo de la amada precisamente por su uso voluptuoso del lenguaje. Más tarde en este ensayo, indago en el erotismo prodigioso de El mono gramático. Por ahora, cabe especificar que el cuerpo tiene distintas representaciones en El mono gramático aparte de las variantes erotizadas - tales como el cuerpo caminante, el cuerpo que lee y escribe, y el cuerpo del mono epónimo- los cuales también se abordarán en mayor detalle a continuación.

Mi objetivo en el presente trabajo es analizar el lenguaje poético en El mono gramático al mismo tiempo que indagar en torno al cuerpo en la misma obra, ya que conceptualizo las relaciones entre el lenguaje y el cuerpo como una dialéctica. Lo que designo en este estudio como la poética del entre es una exploración de la función preposicional de esta palabra que une y separa al mismo tiempo, de espacios - físicos y mentales - y de estados limítrofes. Además de ser una poética en la obra de Paz, el entre representa la experiencia humana de estar vivo en el mundo. Junto al entre como concepto aludido y palabra repetida en $E l$ mono gramático, mencionaré a lo largo de mi análisis los poemas "Entre la piedra y la flor" y "Carta de creencia", aunque sea muy de paso debido a las restricciones del tema y extensión del presente trabajo. ${ }^{3}$ Se harán estas breves referencias para sacar a relucir el hecho de que el entre, en relación constante con el lenguaje y el cuerpo, es un eje fundamental de toda la poética de Octavio Paz.

Para proporcionar apoyo teórico a mi análisis de las características y los desempeños asociados con el entre, consulto dos textos ensayísticos en este trabajo. El primero, una obra de crítica literaria, es el ensayo "Xavier Villaurrutia en persona y en obra", donde Paz propone un vocabulario relevante para la interpretación de su propia obra. El segundo texto es el tratado filosófico Lógica del límite, libro en el que Eugenio Trías considera el carácter limítrofe de los seres humanos, además de ciertos estados y espacios.

\footnotetext{
${ }^{3}$ Existe material suficiente para recopilar una lista de poemas adicionales a los títulos indicados y de ahí realizar una indagación mucho más detenida en el entre en algún estudio próximo.
} 
Antes de consultar aquellas fuentes crítico-teóricas, conviene considerar El mono gramático por sí solo. En este breve libro, un narrador recorre el mismo camino en distintas ocasiones, a veces a solas y otras acompañado por su bella y amada pareja. El camino de Galta en la India, que conduce a un templo abandonado y parcialmente destruido por una tormenta de arena, converge en el texto con Cambridge, Inglaterra, el lugar de la redacción. La caminata llega a ser un proceso tan físico como mental-artístico. Los lectores presencian una peregrinación no solo hacia un lugar verdadero, sino también hacia una comprensión más amplia del acto poético y de la pasión erótica.

Como lectores de este libro, debemos someternos a una experiencia parecida a lo que Paz describe en el mismo: "penetra[r] en la maleza" (1996a: 47) en el sentido de abandonarse a la lectura y dejarse llevar por el lenguaje y las imágenes - tanto las verbales como las pictóricas- que constituyen la obra. ${ }^{4}$ A partir de la primera frase del libro, la cual comienza con una letra minúscula, el lector no sabe firmemente dónde poner el pie, puesto que El mono gramático es a la vez un ensayo experimental, un texto de reflexión y un poema en prosa. En otras palabras, la obra en sí es una representación del entre: mientras resiste la clasificación, El mono gramático traza su propio camino que nos lleva por varios géneros literarios a la vez.

La cuestión de la clasificación literaria no es únicamente de interés para los críticos y los comerciantes de libros. Al contrario, en el caso de El mono gramático es una preocupación enteramente esencial, puesto que el texto comunica una serie de interrogantes tácitas sobre qué es la poesía, por qué y para qué. En este aspecto, El mono gramático está conectado con los libros ensayísticos en los que Octavio Paz explora la poesía y la relación de esta con el mundo. ${ }^{5}$ En parte, El mono gramático es una obra de poética ya que emprende una exploración de la poesía a través de una experiencia de la misma: el libro está hecho de lenguaje poético con el que las posibilidades y los límites del género poético se ponen a prueba.

${ }^{4}$ El texto contiene reproducciones de varias obras visuales (lienzos, fotografías y grabados) que contribuyen al efecto total de la obra. El mono gramático se relaciona con otros proyectos de Paz en los que el lenguaje se observa en diálogo con distintas imágenes gráficas, como es el caso de Discos visuales (1968) y Topoemas (1971), entre otros. Este aspecto de El mono gramático, sin embargo, no es el enfoque del presente trabajo.

${ }^{5}$ Véase El arco y la lira, Los hijos del limo y La otra voz. 
No obstante, El mono gramático no se puede reducir a ningún género específico. Debido a los múltiples puentes que el libro extiende, y todos al mismo tiempo, El mono gramático representa una obra limítrofe. Es un texto que siempre apunta hacia algo más: está entre la prosa y el poema, además de entre la poesía y la poética. Hugo J. Verani señala muy bien el dilema y el logro simultáneos del acertijo genérico que El mono gramático plantea: "Como otras obras modernas inclasificables, [este libro] comprende al ser entero e involucra toda la literatura" (2013: 128). Como ya cité en este trabajo, la poesía representa el centro de la vida y obra de Octavio Paz (Paz citado en Blandin: 56-57). Este fundamento ontológico ofrece un gran apoyo para considerar El mono gramático primero y ante todo como poesía, y más específicamente, como poema en prosa. ${ }^{6}$ Tal categorización concuerda con una definición de la poesía que el mismo Paz ofrece en Vislumbres de la India: "en la poesía se combinan, de manera inextricable, la inspiración y el cálculo” (213).

La dificultad de cualquier intento por fijar la categorización definitiva de El mono gramático es otro reflejo del fenómeno entre. Este desafío representa una clave, y no solo para la lectura de El mono gramático, sino para toda la obra paciana. Es decir, los escritos de Octavio Paz están repletos de yuxtaposiciones, combinaciones inesperadas y pares de opuestos. Para ilustrar este fenómeno, señalo dos fragmentos de $E l$ mono gramático. En uno, se elabora una descripción diáfana de un oleaje de gente en el camino de Galta. Esta se basa en los cinco sentidos del cuerpo humano y está marcada por la fluidez y la libertad del estilo - por ejemplo, una frase abarca dos páginas (101-102). Sin embargo, en el fragmento inmediatamente siguiente, se establece una contradicción total, ya que se refleja críticamente sobre una pintura inglesa del siglo XIX usando un estilo más formal, que está en consonancia con la disciplina de la historia del arte (104-106). Por supuesto, esta combinación de fragmentos bien diferentes es inspirada y calculada (Paz 1996b: 213). ¿Dónde, si no en la poesía, llevar a cabo tal tipo de composición?

\footnotetext{
${ }^{6}$ Como parte de su comentario de El mono gramático, Juvenal Acosta tiene razón al notar que la poesía en prosa constituye un oxímoron. Empero, la contradicción de estos términos contribuye a su aplicación a aquella obra. La combinación de las palabras 'poesía' y 'prosa' es otra muestra del carácter intermedio de El mono gramático, además del deseo que el texto conlleva por superar los límites convencionales (163-185).
} 
El texto de Paz nos permite contemplar el estado entre como una experiencia poética y una experiencia vital. Esto se debe en gran parte al énfasis que se pone en el cuerpo a lo largo de El mono gramático, y más propiamente en el cuerpo que avanza en el sendero de Galta. ${ }^{7} \mathrm{La}$ caminata física y la creación poética se presentan como actos profundamente interconectados. Se nota en la siguiente cita que el narrador atribuye un privilegio especial al camino y que este tiene relevancia tanto para el acto de andar como para el de escribir:

recorrerlo de nuevo (inventarlo a medida que lo recorro) y sin darme cuenta, casi insensiblemente, ir hasta el fin [...] precisamente al comenzar la caminata, tampoco sabía adónde iba ni me preocupaba saberlo. No me hacía preguntas: caminaba, nada más caminaba, sin rumbo fijo. Iba al encuentro... ¿ ¿de qué iba al encuentro? Entonces no lo sabía y no lo sé ahora.... (11).

Las últimas frases apuntan a una realidad interesante: en la caminata así como en la escritura, el procedimiento es tal vez más importante que cualquier resultado. El fin no consiste en llegar a un punto determinado, sino en embarcarse en un viaje en el cual el territorio recorrido y lo que queda por delante tienen igual importancia. Debido a la circularidad estructural y el hecho de que el mismo camino se transita y se cuenta varias veces, todo el libro bajo estudio ocupa el espacio entre el comienzo y el final, tanto de la peregrinación como de la escritura del mismo libro. Entre las páginas de El mono gramático, el narrador así como el lector se dedican a la tarea de seguir y explorar caminos, sin insistir demasiado en cualquier resultado final.

Junto a la obra paciana, Lógica del límite aprovisiona un punto de referencia para mi consideración del entre. En este libro, Eugenio Trías identifica la naturaleza del ser como limítrofe (18). Asimismo, el ser es: "la cópula-disyunción (y/o) entre lo que puede llamarse la categoría (ámbito del pensar-decir, del predicar y significar, o designar) y la cosa, replegada 'en sí', o lo que se presupone sin poderse conceptuar ni concebir (ni designar)" (310; cursivas del autor). Como un punto de contacto y separación entre los extremos de la experiencia humana, el ser tiene una presencia simultánea en órbitas muy distintas. Por una parte tene-

${ }^{7}$ El trabajo de Verani sobre la poética de la caminata es iluminador. Véase su libro de 2013, Octavio Paz: el poema como caminata, que se titula igual que un artículo de 2009. 
mos el cuerpo y el lenguaje con que nos expresamos. Por la otra, existe todo lo indecible - otro tipo de realidad no menos verdadera, aunque imposible de articular. El ser es dialéctico. Es una representación de la bisagra ("/”) que vincula y mantiene separadas dos esferas (que son, además, las mismas imágenes de su existencia).

La importancia que Trías concede al espacio/estado entre coincide en varios planos con el pensamiento de Paz. Una de las semejanzas más relevantes para el presente estudio es la idea ya expuesta de lo indecible. Esa es una preocupación central en El mono gramático y más generalmente en toda la obra paciana. Tanto para Paz como para Trías, el motivo del arte es el deseo de explorar y dar expresión a los matices de la vida que parecen resistir cualquier designación. Es más, el filósofo español precisa que la tarea de la filosofía consiste en dialogar con el arte para determinar qué es lo indecible (Trías: 218; 320). Dicho concepto se entreteje en los propios límites del pensamiento, tanto en el proceso poético como en el filosófico. Las zonas fronterizas son lugares fértiles desde los cuales puede surgir "una concepción nueva de la realidad" (293).

Esta idea del límite como un espacio o un estado que genera nuevas imágenes de la vida y de las experiencias corresponde con el epígrafe al presente artículo, donde Octavio Paz identifica el dualismo como una condición de "la sabiduría" (1996a: 17). Es útil tener en mente que los límites no son espacios estáticos. Al contrario, el entre es el escenario de percepciones y pensamientos que saltan continuamente de un lugar a otro: "el cambio se resuelve en fijezas que son acuerdos momentáneos [...] la sabiduría está en lo instantáneo. Es el tránsito” (16-17). En El mono gramático sobresalen este y otros momentos de atención prestada a las conexiones que son también fisuras. La cita siguiente sirve de ejemplo: "La mesa y el bote de basura, las paredes de ladrillo y el piso de cemento, encierran al espacio. ¿Lo encierran o son sus puertas?" (15). La materialidad de los objetos cotidianos se contrapone al pensamiento abstracto acerca de la dimensión espacial. Si nos perdemos en el juego de contrastes, no caemos en una trampa verbal, sino que caemos en la cuenta de la "sabiduría" que Paz advierte. En otras palabras, entre el encierro y la apertura o entre los objetos y el pensamiento se hallan nuevas imágenes de la realidad (Trías: 293).

Como se ha apuntado posteriormente, la poesía como caminata es otra imagen de la búsqueda acerca de los límites del ser y del estado de ser (Verani 2009 y 2013). Las conexiones entre los procedimientos lite- 
rarios y los del narrador-caminante de El mono gramático se presencian a través de varios términos técnicos que se usan para analizar la poesía. Partiendo de la idea del verso, de la línea o de la expresión poética como un camino textual, hay que considerar palabras como 'pie', 'métrica' y 'encabalgamiento', las cuales se emplean para estudiar y criticar la poesía. Gracias a ellas, se observan las relaciones entre la literatura y la vida cotidiana basadas en las experiencias del cuerpo. Es cierto que nuestra referencia primaria al ritmo, fundamento del lenguaje poético, se deriva de nuestras experiencias físicas. El latido del corazón, el torrente de las trayectorias que la sangre emprende para mantener la vida, y el ritmo constante de nuestros pasos proporcionan claros ejemplos de esta realidad. Así, usamos un término corporal, el pie, para trazar una unidad métrica en la poesía. Se mide el progreso a través de un poema igual que el pasar del cuerpo a través del espacio y del tiempo. Asimismo otro tropo poético, el encabalgamiento, tiene su homólogo somático: un verso parece saltar y así integrarse en otro al estilo de unos pies humanos que siguen adelante. El empleo de tales términos sobre todo corporales para aproximarnos a la literatura sugiere que esta es, verdaderamente, un reflejo de la experiencia más básica de los seres humanos, ya que definimos nuestra existencia según las capacidades y los límites del cuerpo. La poesía cobra cuerpo y de hecho, llega a representar un cuerpo a su propio modo. La poética del camino, que refleja un estar en curso, es una variación de esta preocupación más general en toda la obra de Octavio Paz acerca de las relaciones entre el lenguaje y el cuerpo.

El mono gramático y otros textos de Paz donde se trazan caminos son representativos del vitalismo, no solo en la poesía sino en la experiencia limítrofe que es estar en el cuerpo y en el mundo. El cuerpo en movimiento es análogo al tránsito de la vida y el destino desconocido de esta en la muerte. Se hallan ejemplos impactantes de esta comparación en el poema temprano "Entre la piedra y la flor", donde Octavio Paz evoca el "trote obstinado de animal humano" (Paz 1997a: 88). ${ }^{8}$ Desde el

\footnotetext{
${ }^{8}$ En su estudio de la poética de la caminata, Verani analiza "Entre la piedra y la flor" y relaciona este poema con otros, algunos que también menciono en el presente ensayo. Es más, el libro de Verani provee criterios para el análisis más detallado del fenómeno entre en toda la poesía de Octavio Paz (Verani 2013). Sin que se pueda hacer un estudio comprensivo aquí, señalo algunos de los ejemplos más llamativos para dar una idea de la relevancia del entre no solo en El mono gramático sino en la obra paciana completa.
} 
paisaje de Yucatán, el yo poético observa al ser humano y su condición de existir entre espacios divididos y condiciones opuestas. No obstante, el poema sugiere paradójicamente que lo limítrofe es de hecho una experiencia de plenitud:

Entre la piedra y la flor, el hombre:

el nacimiento que nos lleva a la muerte,

la muerte que nos lleva al nacimiento.

La imagen del hombre "entre la piedra y la flor" tiene profundas resonancias con otras que se elaboran no solo en la poesía de Paz sino también en su obra ensayística. Ahora bien, en la obra de Octavio Paz la destreza del autor como lector tiene una importancia equivalente respecto a la habilidad para crear textos nuevos. La lectura y la escritura son actividades mutuamente fértiles con las que el autor se entrena, se enfrenta y se lanza, todo en relación con la literatura. En esta misma línea, es lícito examinar un texto ensayístico de Paz donde encontramos más pautas útiles para la consideración del entre. En el prefacio a una antología de la poesía de Xavier Villaurrutia, Octavio Paz identifica la preposición entre como una clave del arte y pensamiento de aquel autor, quien fuera desde luego un mentor poético para Paz (Paz 1980: 60-61). La observación sobre el entre en la obra de Villaurrutia es ilustrativa de la tendencia por parte de Octavio Paz de realizar lecturas "parciales e interesadas" (Stanton: 56) de poemas y poetas específicos. Es decir, cuando Paz escribe sobre la poesía de los demás o la poesía en general, también desarrolla, pule y promueve sus propios poemas y su poética. La lectura, la crítica, la teoría y la creación literarias son actividades inseparables para Paz. Efectivamente, en el siguiente comentario, Paz realiza una interpretación sensible que arroja luz no solo sobre la obra de Villaurrutia sino asimismo - y de mayor interés para el presente estudio— sobre su propia obra:

Villaurrutia no se propuso en sus poemas la transmutación de esto en aquello — la llama en hielo, el vacío en plenitud - sino percibir y expresar el momento del tránsito entre los opuestos. El instante paradójico en que la nieve comienza a obscurecerse pero sin ser sombra todavía. Estados fronterizos en los que asistimos a una suerte de desdoblamiento 
universal. En ese desdoblamiento no somos testigos [...] de la coincidencia de los opuestos sino de su coexistencia. La palabra que define a esta tentativa es la preposición entre. En esa zona vertiginosa y provisional que se abre entre dos realidades, ese entre que es el puente colgante sobre el vacío del lenguaje, al borde del precipicio, en la orilla arenosa y estéril, allí se planta la poesía de Villaurrutia, echa raíces y crece (Paz 1980: 60, cursivas del autor).

Sin considerar la poesía de Villaurrutia en esta ocasión, es evidente que el pasaje citado representa una elocuente cristalización del entre y su relevancia para el pensamiento y la poética de Octavio Paz. Es notable que el juicio crítico de Paz incluya referencias al universo - donde los opuestos coexisten y donde el ser humano también existe entre y gracias a ellos_ - además de referencias a la razón de ser del lenguaje: la de representar, aunque fuera muy provisionalmente, las realidades de aquel universo y los seres que lo habitan. Se aprecia cómo Paz delinea una poética del entre con menciones de los procedimientos biológicos de los entes vivos: de acuerdo con la perspectiva de Paz, la poesía "se planta [...] echa raíces y crece" (60). Sin duda, el entre identificado en la obra de Villaurrutia sigue extendiendo más raíces y nuevas ramas en los escritos del propio Paz.

Hay que añadir que este tipo de lectura interesada o parcial, tal como Anthony Stanton la describe (56), no es solamente auto-reflexiva sino también marcada por una profunda predilección. A causa de la evidente pasión de Octavio Paz por la poesía y las palabras en sí, se puede hablar del erotismo literario en el sentido de un anhelo constante hacia el lenguaje mismo. Junto al erotismo sexual de pareja, que también tiene una presencia indeleble en El mono gramático, la erotización del lenguaje y de la literatura sugiere un sentido más global del texto bajo estudio. En Solo a dos voces, Octavio Paz identifica esta índole de interfecundación entre el lenguaje y el cuerpo como una representación de su experiencia de la India: "Donde encontramos la erotización de las ideas es en la India. Ahí los conceptos se sexualizan, se vuelven cuerpo. Los sistemas son conjunciones eróticas" (Paz y Ríos 1973: sin paginar). El sánscrito provee un ejemplo fascinante: "Según los textos tántricos, las consonantes del alfabeto son femeninas y las vocales masculinas; unión sexual de los fonemas, el sánscrito se funda en una teoría erótica y metafísica del lenguaje" (Areta: 158). Aunque semejantes principios 
ontológicos le sirven a Paz como fuente de conocimiento e inspiración, sería equivocado suponer que El mono gramático representa solo una ilustración de la influencia de la India en el pensamiento y la escritura de Octavio Paz.

Al contrario, las reflexiones sobre la historia y las culturas de Oriente constituyen una parte integral de la poética más general de Paz. Con razón, Rachel Phillips señala que la influencia de la India y otras civilizaciones del Este en la obra paciana representa un aporte ya natural dentro del contexto más amplio del viaje epistemológico que emprende este autor en toda su carrera poético-filosófica (31). Paz residió durante largos periodos en la India, primero como secretario de la embajada mexicana y luego como embajador entre 1962 y 1968 . Además, realizó varios viajes antes y después de estos años. Junto a El mono gramático, no es menos notable la presencia de la India en varias obras de Paz, ya sea poéticas — por ejemplo, Ladera este- o críticas — por ejemplo, Conjunciones y disyunciones. Es evidente que la India representa una fuente aparentemente inagotable de fascinación e inspiración para Paz, y que estimuló en aquel autor el examen de ciertas preguntas y problemáticas desde una variedad de acercamientos, una y otra vez. En Vislumbres de la India, Paz reconoce abiertamente la profunda influencia del contacto con las culturas, la historia y las sociedades de la India no solo dentro de su obra, sino también en su vida diaria y espiritual (1996b: 30).

Inmerso en este mundo que produjo tantas huellas en su visión del mundo y del arte, Paz dejó su puesto como embajador a manera de protesta contra la masacre estudiantil que ocurrió en Tlatelolco el 2 de octubre de 1968. Escribe Paz: "Decidí que no podía continuar representando a un gobierno que había obrado de una manera tan abiertamente opuesta a mi manera de pensar" (1996b: 216). Cuando leemos en El mono gramático: "Las relaciones entre la retórica y la moral son inquietantes: es turbadora la facilidad con que el lenguaje se tuerce y no lo es menos que nuestro espíritu acepte tan dócilmente esos juegos perversos" (1996a: 25), nos enfrentamos con una crítica que se enfoca tanto en una filosofía artística como en las realidades políticas de México en 1968, a la par que con circunstancias perturbadoras en otros países como Estados Unidos, Francia y Alemania. La política personal de Paz frente a las revueltas populares es clara. Él siguió los acontecimientos de cada país "con asombro y con esperanza" (1996b: 212) y en el caso 
de su patria, abogó por la necesidad de una reforma democrática y se opuso rotundamente a la brutalidad empleada por el gobierno.

Después de marcharse de la India Paz publica Posdata, una obra ensayística que sirve como continuación de El laberinto de la soledad y comentario sobre la revuelta de los estudiantes mexicanos que precedió a la masacre. En este libro Paz postula que la corrupción del lenguaje es la primera señal de un problema grave a nivel social (1982: 76). De ahí subraya la importancia de la gramática como elemento crítico con posibilidades reconstitutivas. Por medio de la crítica del lenguaje se explora y critica la realidad - unas empresas sin duda esenciales para que se llegue a cualquier solución. Cuando Paz describe la literatura como "una reflexión sobre el lenguaje y una tentativa por inventar otro lenguaje: un sistema de transparencias para provocar la aparición de la realidad" (77), podría estar describiendo El mono gramático, obra que iba a publicar dos años más tarde. El escritor hace frente a una tarea múltiple y colosal: debe pensar en el lenguaje y reinventarlo. Debe producir la revelación de nada menos que la — ¿o una? — realidad, como si sacara a la luz una cara escondida.

Con semejantes expectativas literarias en mente, no parece extraño que Paz hubiera elegido apelar a un guía para acompañarlo en el viaje que emprende luego. Este es el propio simio que da nombre a $E l$ mono gramático. A manera de epígrafe al libro, Paz cita el diccionario de John Dowson sobre la mitología hindú. Este texto provee unos datos introductorios sobre el mono gramático, conocido bajo los nombres Hanumān, Hanumat y Hanūmat. El jefe de los monos es gramático/ poeta, hijo del viento y capaz de volar (Dowson: 116-117). Cuando Paz evoca el mono mítico, participa en una rica y compleja tradición poética. En las afueras de Galta viven no solamente bandadas de monos, sino también una casta de parias, los Balmik, que veneran a Hanumān. La casta toma su nombre de Vālmìki, quien era un paria leproso, según una leyenda (1996a: 127). Hanumān aparece en el Rāmāyana, un poema épico antiguo, escrito en sánscrito y atribuido a Vālmīki. En esta obra el mono ejecuta un salto increíble desde la India hasta Lankā, lugar del reino del demonio Rāvana, quien tenía presa a la mujer del héroe del Rāmàyana. Se dice que Hanumān también compuso un texto sobre los mismos asuntos descritos en el Rámāyana. Al leer las palabras del mono escritas en unas rocas, el poeta Vālmīki le pidió a Hanumān que las destrozara, puesto que temía que su propia obra fuera eclipsada 
por la del mono-poeta (135). Es más, existen vínculos entre Hanumān y el simbolismo del mono en otras culturas. El dios egipcio de la escritura se representa a menudo como un mono y, en el Oeste, la cultura azteca predica que "los nacidos bajo el signo del Mono serían poetas, músicos, personas dotadas para las artes" (Ríos: 42-43). ${ }^{9}$

En El mono gramático Hanumān representa nada menos que la poesía personificada. Esta imagen resulta todavía más útil por lo que connota en la India: el mono simboliza una poesía que cobra cuerpo. Es una encarnación del arte en el sentido de ser un punto de encuentro entre el cuerpo y el lenguaje poético, además de un participante en el ciclo de la creación y la re-creación. Vuelvo a decir que Hanumān es un guía para Paz - también lo es para el narrador y los lectores de El mono gramático. Su presencia en una variedad de esferas - la mitología, su propio texto y los de otros, el salto físico que le permite estar en dos reinos casi simultáneamente- señala a Hanumān como un representante de la idea del ser limítrofe:

el ser físico-metafísico que expresa y manifiesta, habitando, el gozne entre lo de aquí, el ser-aqui y lo de allá, el ser-allá. En él se proyecta, como decir y figurar, como pensar y como obrar ese espacio en que habita y al cual revela y manifiesta, o expresa. Habitando lo piensa, lo configura, lo significa y manifiesta: habitando ese espacio que puede serle propio, el espacio del gozne o de la bisagra, que es un espacio figurativo-simbólico, medianero y hermenéutico.... (Trías: 304; cursivas del autor).

Como animal y como poeta, el mono gramático representa una fusión poco común de características y habilidades. Su 'escritura' en la naturaleza pone en tela de juicio las nociones acerca de lo que es el arte. Es más, sus movimientos corporales se interpretan como actos de creación. En una descripción de una estatua de Hanumān en el camino de Galta, el narrador de El mono gramático advierte que el salto del mono representa cierta forma de dibujo. La hazaña física se describe como "espiral: línea / liana / vía láctea” (1996a: 126). Como ser limítrofe-poético por excelencia, Hanumān percibe y refleja una pluralidad de realidades. Su gesto corporal produce una serie de analogías entre la poesía (línea), la naturaleza (liana) y el cosmos (vía láctea). El salto abre camino a unas

\footnotetext{
${ }^{9}$ Jacques Lafaye incluye información interesante sobre el título de El mono gramático y sus asociaciones con la literatura y la mitología de varias culturas (43).
} 
posibilidades relacionadas con lo indecible, este concepto desarrollado en varios escritos de Paz, además de en la teoría de Trías. El salto del mono es "descomunal" (126) porque consiste en salvar un umbral entre dos reinos distintos. A su vez, los saltos narrativos en el texto de Paz establecen metáforas que expresan unas verdades que pueden parecernos paradójicamente indecibles. Sin duda, estamos en un territorio poético: un lugar dialéctico en que se generan imágenes nuevas.

Perteneciente a la representación que Hanumān realiza del entre, Acosta emplea un apto neologismo, el de "hu-mono" (171). Con este término se enfatiza hasta qué punto el narrador y el mono son reflejos el uno del otro. El salto físico del mono gramático inspira otros saltos en el lenguaje de Paz. Durante este viaje igualmente físico y psíquico, una cosa conduce rápida e inesperadamente a la otra, como si el narrador estuviera volando libremente entre ellas. El salto de Hanumān entre las orillas resulta en un estado de convergencia provisional. Siguiendo a Hanumān, con El mono gramático Paz ejecuta saltos temático-lingüísticos: "La visión de la poesía es la de la convergencia de todos los puntos [...] La convergencia es quietud porque en su ápice los distintos movimientos, al fundirse, se anulan; al mismo tiempo, desde esa cima de inmovilidad, percibimos al universo como una asamblea de mundos en rotación" (134-135). Se podría añadir que la visión de la poesía se realiza en el entre. Desde este punto de contacto entre opuestos - el salto y la inmovilidad - se entrevé otra imagen de la verdad en un nivel cósmico.

A tal propósito, reflexionemos brevemente en una observación de Paz acerca de las contradicciones en la literatura y también en la vida: "no hay verdades simples y cada obra contiene su negación, su crítica [...] la pluralidad de significados de las palabras [...] corresponde a la pluralidad de seres que somos y a la complejidad de la realidad. La literatura debe decir esa pluralidad" (Paz y Ríos: sin paginar). Ya vimos que la tarea de criticar el lenguaje consiste por supuesto en usar y explorar ese mismo conjunto. El resultado es una síntesis destructorarenovadora, o sea, una re-creación. Los sistemas del lenguaje y del cuerpo repiten, recrean y se dirigen a la complejidad de la realidad. Deben, como Paz arguye, expresar la pluralidad de nuestra experiencia que está marcada por los límites del lenguaje y del cuerpo. Las palabras cobran cuerpo y el cuerpo a su vez vuelve a ser un sistema comunicativo.

$\mathrm{El}$ individuo que usa el lenguaje también usa su cuerpo y así emprende una tarea física e intelectual. Al leer, nuestros ojos — por no 
hablar de las neuronas - llevan a cabo una serie compleja de funciones para que podamos sumergirnos en la realidad de un texto, escuchando mentalmente el lenguaje que nos transmite mensajes e impresiones. El lenguaje carece de sentido sin la presencia de un cuerpo con que experimentarlo. Se diría lo mismo respecto al procedimiento de la escritura. El lenguaje existe en función del cuerpo que lo compone a través de una miríada de procesos desarrollados por la mente, los ojos y las manos del escritor. Es más, ese lenguaje también depende de los lectores que lo activen por medio de la lectura. Así se explican los múltiples recordatorios en el texto de Paz sobre los procesos físico-mentales de leer y escribir. Cito, como ejemplo, el siguiente pasaje: "ahora mismo mis ojos, al leer esto que escribo, inventan la realidad del que escribe esta larga frase" (1996a: 53).

No obstante la función emblemática de Hanumān como encarnación de la poesía, el mono desempeña otro papel todavía más considerable por ser un nexo entre el cuerpo y el lenguaje. Él está entre el mundo enteramente físico y la esfera de la expresión poética. Su propio ser ilustra perfectamente un axioma de la obra bajo estudio: "[que] todo cuerpo es un lenguaje [...] La poesía es corporal: reverso de los nombres" (123-124). Aparte de hacer hincapié en la inseparabilidad del lenguaje poético y del cuerpo, esta frase revela un rechazo del concepto nominalista del lenguaje. Paz plantea que las ideas, experiencias e imágenes comunicadas lingüísticamente son mucho más que meras palabras. Escribir un poema es crear un cuerpo. El poema se deshace y se recrea con cada lectura crítica. Por eso Paz insiste en el papel del lector como parte del proceso poético, ya que la literatura depende tanto de la escritura como de las lecturas múltiples que se hacen de ella. Es una criatura que todos creamos y recreamos y a través de la cual buscamos reconciliar al cuerpo con el lenguaje.

Es notable que el texto de Paz se entretenga más en los actos físicos de Hanumān, aun si esos suelen sugerir actitudes esencialmente poéticas: "Hanumān salta de la barda al suelo, permanece un instante agachado, se yergue, escruta los cuatro puntos cardinales y, con decisión, penetra en la maleza" (47). Esta última acción indica una tarea básica y necesaria del "hu-mono" (Acosta: 171). De nuevo, percibimos que el lenguaje poético depende no solo de los nombres, sino de una esencia e inmediatez física. La enumeración de las especies vegetales y de sus propiedades asombrosas sirve para reconstruir un tipo de selva a la vez 
evocadora de la naturaleza que debe representar, pero también de otra que es verbal. Gracias al lenguaje, un ambiente de espesor voluptuoso y casi agobiante nace en la página. De veras, hemos penetrado en una maleza tan física como figurativa:

El camino es escritura y la escritura es cuerpo y el cuerpo es cuerpos (arboleda). Del mismo modo que el sentido aparece más allá de la escritura como si fuese el punto de llegada, el fin del camino (un fin que deja de serlo apenas llegamos, un sentido que se evapora apenas lo enunciamos), el cuerpo se ofrece como una totalidad plenaria, igualmente a la vista e igualmente intocable: el cuerpo es siempre un más allá del cuerpo (1996a: 123).

El dicho "más allá del cuerpo" se relaciona con la representación en toda la obra paciana del amor erótico. A la par con el lenguaje poético, el erotismo es otra vía en la obra de Octavio Paz para experimentar la trascendencia momentánea de los límites que definen al ser humano. En La llama doble Paz se refiere a ese mismo potencial del amor erótico: "el amor es, simultáneamente, conciencia de la muerte y tentativa por hacer del instante una eternidad [...] hay un instante de dicha que no es exagerado llamar sobrehumana: es una victoria contra el tiempo, un vislumbrar el otro lado, ese allá que es un aquí, en donde nada cambia y todo lo que es realmente es" (1993: 212-213; cursivas del autor). Un pasaje de El arco y la lira demuestra que la otredad para Paz es de hecho lo que llamamos la poética del entre en el presente trabajo:

Experiencia hecha del tejido de nuestros actos diarios, la otredad es ante todo percepción simultánea de que somos otros sin dejar de ser lo que somos y que, sin cesar de estar en donde estamos, nuestro verdadero ser está en otra parte. Somos otra parte. En otra parte quiere decir: aquí, ahora mismo mientras hago esto o aquello. Y también: estoy solo y estoy contigo, en un no sé dónde que es siempre aquí. Contigo y aquí: ¿quién eres tú, quién soy yo, en dónde estamos cuando estamos aquí? (2005: 266; cursivas del autor).

Paz cuenta el abrazo sexual entre aquellos "actos diarios" y considera que el erotismo constituye otro entre donde es posible "percibir y expresar el momento del tránsito entre los opuestos" (1980: 60). Volviendo al ensayo de Octavio Paz sobre la poesía de Xavier Villaurrutia, encon- 
tramos elaboraciones en torno al vocablo 'entre'. En el párrafo final del ensayo, Paz emplea la palabra 'pliegue' de una manera que permite conectar más precisamente la modalidad del entre con una poética erótica. El pasaje citado a continuación, como tantos otros de la obra completa de Paz, desarrolla un erotismo doble. Por un lado, hallamos el amor erótico de pareja y por el otro, el deseo hacia y entre las combinaciones de letras y palabras. En ambos casos, la sensualidad apunta hacia el ya citado "más allá del cuerpo" (1996a: 123) que es asimismo un más allá del lenguaje. He allí manifestaciones adicionales de la otredad en la obra paciana:

El entre es el pliegue universal. El doblez que, al desdoblarse, revela no la unidad sino la dualidad, no la esencia sino la contradicción. El pliegue esconde entre sus hojas cerradas las dos caras del ser; el pliegue, al descubrir lo que oculta, esconde lo que descubre; el pliegue, al abrir sus dos alas, las cierra; el pliegue dice No cada vez que dice Sí; el pliegue es su doblez: su doble, su asesino, su complemento. El pliegue es lo que une a los opuestos sin jamás fundirlos, a igual distancia de la unidad y de la pluralidad. En la topología poética, la figura geométrica del pliegue representa al entre del lenguaje: al monstruo semántico que no es ni esto ni aquello, oscilación idéntica a la inmovilidad, vaivén congelado. El pliegue, al desplegarse, es el salto detenido antes de tocar la tierra - ¿y al replegarse? El pliegue y el entre son dos de las formas que asume la pregunta que no tiene respuesta (1980: 61).

El pliegue es una imagen del sexo femenino, de la espiral, de la vía láctea y del universo entero. A la manera de los caracoles, es una boca que contiene el eco de sus propios orígenes, aun cuando esté apartada de aquellas olas. El pliegue es una figura del vacío y al mismo tiempo, de la plenitud. Contiene enigmas ("la pregunta que no tiene respuestas") y no contiene nada aparte del potencial de conexiones y transformaciones, puesto que es otro símbolo del: "entre: el hueco. Pausa universal, vacilación de las cosas entre lo que son y lo que van a ser" (61; cursivas del autor). El pliegue es un locus de creación y crecimiento. Al contrario de su pareja binaria, el puente ${ }^{10}$ - que es una imagen

\footnotetext{
${ }^{10}$ Está claro que el puente es muy representativo del fenómeno entre que estudiamos en el presente análisis. Véase por ejemplo el poema "Carta de creencia" donde se repite el siguiente verso: "Las palabras son puentes" (2004: 174-175). Verani hace un
} 
de la virilidad y la expansión masculinas- el pliegue contiene la dualidad más básica ("las dos caras del ser") y pone palabras a lo indecible ("dice No cada vez que dice Sî").

Así es que el pliegue, como expresión del entre, adquiere un significado erotizado asociado con el cuerpo de la mujer, además de un potencial poético que tiene su analogía en el cosmos — donde los opuestos forman una totalidad. Estos tres elementos de cuerpo, lenguaje y universo reaparecen una y otra vez en El mono gramático y tantos otros escritos de Paz porque se asocian con la búsqueda de la otredad, la que se puede considerar el meollo de toda la obra de este autor. El narrador de El mono gramático se presenta en relación con una 'otra' específica: Esplendor, su compañera peregrina y amante. Esta mujer tiene una identidad que no se describe sino como múltiple, puesto que ella se transforma perpetuamente. En primer lugar, Esplendor aprovisiona un ejemplo notable en cuanto al cuerpo erótico. Establece desde su primera aparición en el texto una fuerte presencia sexual. De repente, en la mitad de un párrafo largo que es todo un capítulo en sí, "Esplendor se desnuda con una mano sin soltar con la otra la verga de su pareja" (1996a: 42). Sin la presencia de esta frase corta aunque significativa, el capítulo se habría podido leer como una descripción material del lenguaje: "espesura indescifrable de líneas, trazos, volutas, mapas" (41). Entonces, el pasaje subraya el doble erotismo desde los dos puntos de vista previamente notados. Primero, tenemos el encuentro erótico mismo y segundo, el carácter altamente sensual del lenguaje. La "espesura" es el dibujo del fuego sobre una pared en el camino de Galta y el telón de fondo para la primera descripción abiertamente sexual. Constituye otra etapa en el oscurecimiento de los límites entre el lenguaje y el cuerpo. Mientras el lenguaje se observa en términos de una realidad somática, el cuerpo se revela como un sistema representativo. En coordinación con "el discurso del fuego" (41), las sombras parecen inscribir los movimientos corporales del narrador y de Esplendor en la pared: "Las sombras se enlazan y cubren todo el muro. Se desenlazan [...] Se enlazan y desenlazan los reflejos, las llamas, las ondas. Sombras

recorrido comprensivo de los puentes de palabras y la relación de estos con la otredad en distintos poemas (2013: 156-157; 163-164). El aspecto nuevo con el que quiero contribuir es la erotización del entre y la asociación femenina del pliegue. 
trémulas sobre el espacio que respira como un animal, sombras de una mariposa doble que abre, cierra, abre las alas" (42).

La "mariposa doble" recuerda las "dos alas" que Paz atribuye al pliegue (1980: 61). Asimismo, ambas imágenes son sugestivas de la vagina. Sin embargo, aquel primer encuentro sexual de El mono gramático es literalmente falocéntrico, puesto que este pasaje describe un acto de felación. Nuevamente, el discurso erótico revela una preocupación existencial y poética. En este sentido, la excitación del narrador tiene reflejos en el deseo más generalizado de crear —e intercambiar conlas combinaciones y variaciones tanto del lenguaje poético como del universo. De este modo, Esplendor representa un entre físico y lingüístico, además de una vía hacia el cosmos para el narrador. El papel que Esplendor desempeña es esencialmente complementario en relación con la identidad y los actos del yo poético de El mono gramático.

En otro nivel, Esplendor es una criatura mítica en la cosmología védica. El decimoquinto fragmento de El mono gramático es una mezcla de traducción e interpretación de un pasaje de un texto litúrgico, Satapatha-Brâhmana, en el que se describen los orígenes de Esplendor. Igual que en el texto de Paz, esta mujer intensamente hermosa aparece repentinamente: "erguida, resplandeciente, radiante, centelleante. Apenas la vieron, los dioses la desearon" (81). Al final del fragmento, se presenta el tercer nivel de la identidad de Esplendor: "El Poema no es otro que Esplendor" (82). Con "Poema" se refiere al texto litúrgico, pero otro tanto puede decirse del texto de Paz y de la poesía en general. La encarnación de Esplendor es doble porque representa tanto al cuerpo como al lenguaje.

Mientras que El mono gramático plantea la noción paradójica de que el cuerpo es visible pero no tangible (123), también proporciona un acercamiento interesante con que dirigirse a esta misma problemática. La tendencia en el texto hacia una representación parcial del cuerpo erotizado nos guía hacia una resolución. Por ejemplo, la siguiente descripción física está basada en la fragmentación del cuerpo de Esplendor: "nunca el cuerpo sino sus partes, cada parte una instantánea totalidad a su vez inmediatamente escindida, cuerpo segmentado descuartizado despedazado, trozos de oreja tobillo ingle nuca seno uña, cada pedazo un signo del cuerpo de cuerpos, cada parte entera y total" (63). Como la literatura y como el universo, Esplendor se percibe por medio de sus partes constitutivas. Como el len- 
guaje, el cuerpo se ha vuelto un sistema de signos y puede funcionar linguístico-literariamente como una sinécdoque; tropo con el cual se designa un todo con el nombre de una de sus partes. Desde luego, el proceso de descuartización ilumina otra similitud entre el lenguaje y el cuerpo. Los actos poéticos, igual que los eróticos, implican cierta violencia. Gemma Areta explica que la violencia en la poesía se debe al "indagar del poeta dentro de [las palabras], ese violentarlas para penetrarlas" (158). El cuerpo de Esplendor se somete a este mismo proceso violento durante el acto amoroso. Mediante la descuartización del cuerpo, se expresa una tentativa por 'tocar' o dirigirse a las realidades inefables del cuerpo. Entre el narrador y Esplendor queda un territorio infranqueable todavía. A lo mejor, la cercanía que es condición del acto amoroso le impide al hombre percibir (ver, tocar, abrazar) a la mujer completa.

La descuartización en El mono gramático es además representativa de un deseo de lograr un estado de unidad. Es claro que el cuerpo y el lenguaje son mucho más que meros conjuntos de sus partes respectivas. Al contrario, aquéllos son totalidades que el narrador trata de 'tocar' y re-integrar a través de fragmentos. Esplendor, según lo que Paz recuenta de Satapatha-Brâhmana, se divide en diez partes: una para cada uno de los diez dioses que la desean. Para recobrar su entereza inicial, Esplendor comete un acto de revolución lingüística: "[dice] la oración de la invitación y los dioses [aparecen]. Entonces [dice] la oración de la adoración, al revés, comenzando por el fin, para que todo [regrese] a su estado original [...] Así [vuelve] a ser Esplendor" (81). El cuerpo luminoso de Esplendor es una encarnación poética porque deviene a través de un proceso místico de destrucción y re-creación. También es una expresión máxima del cuerpo anhelado, ese elemento más básico del erotismo. Esplendor es, como escribe Paz en La llama doble: "una forma que, por un instante, es todas las formas del mundo" (1993: 204). Hemos llegado a la plenitud dialéctica de la sinécdoque: una parte puede designar un todo, y también un todo puede designar una parte. Poco a poco nos acercamos hacia una entidad por medio de los componentes de esta. La totalidad del cuerpo es ahora 'tangible'.

Así pues, en la "Universal copulación extática" (1996a: 72) que Paz describe a través de los encuentros amorosos entre los protagonistas de El mono gramático, en la sensualidad de la geografía y en el erotismo del lenguaje mismo se presencia: "una de las respuestas que el hombre 
se ha inventado para mirar de frente a la muerte [...] En el amor todo es dos y todo tiende a ser uno" (1993: 131). El amor erótico establece otros puentes y pliegues entre las divisiones binarias. El abrazo amoroso conduce a uno de los límites más extremos del cuerpo. Allá, en el éxtasis erótico - un estado muy parecido a lo que Trías llama "la cópuladisyunción" (310) — se supera la separación al mismo tiempo que se honran las diferencias entre el yo-narrador de El mono gramático y su 'otra'. Se logra entonces una reconciliación momentánea de las partes fragmentadas, lo que posibilita la percepción de 'otra' realidad:

Esplendor es esta página, aquello que separa (libera) y entreteje (reconcilia) las diferentes partes que la componen,

aquello (aquella) que está allá, al fin de lo que digo, al fin de esta página y que aparece aquí, al disiparse, al pronunciarse esta frase,

el acto inscrito en esta página y los cuerpos (las frases) que al entrelazarse forman este acto, este cuerpo (1996a: 140).

Así se completa el proceso de fusión entre el cuerpo, la poesía y el camino. Esplendor es la página misma, el lugar de la poesía, la materia —en los sentidos de sustancia, herramienta e inspiración- del acto creativo.

Este y semejantes momentos de apogeo en El mono gramático no se realizan a través de la superación de los límites, sino gracias a una aceptación de los mismos. La poética del entre es vital en la obra de Octavio Paz precisamente porque morar en los espacios y estados intermedios del lenguaje poético es, asimismo, vivir como ser humano: es decir, existir plenamente en nuestra realidad, siendo esta una existencia de intermedio entre el nacimiento y la muerte. Esta concepción es la misma que Trías se hace del ser humano como: "el ser físico-metafísico que expresa y manifiesta, habitando, el gozne entre lo de aquí, el ser-aqui y lo de allá, el ser-allá" (304; cursivas del autor).

Para concluir, conviene recordar que las instancias en que Octavio Paz observa, reconoce, habita y honra las dualidades de la vida constituyen grandes hitos de su prolífica obra completa. El comienzo de "Carta de creencia”, uno de sus poemas de amor más impactantes, provee un bello ejemplo: 
Entre la noche y el día hay un territorio indeciso.

No es luz ni sombra: es tiempo.

Hora, pausa precaria, página que se obscurece, página en la que escribo, despacio, estas palabras.

(2004: 173)

Aquel "entre" con que se inicia la "Carta de creencia" es el mismo "territorio indeciso" y la misma "página” en la que Octavio Paz compuso El mono gramático. La poética del entre tan presente en el enigmático poema en prosa está, a fin de cuentas, omnipresente en la obra completa de nuestro autor a causa de las profundas resonancias que establece con la vida, ese "estado intermedio" que Paz señala en la obra de Villaurrutia y que exalta en sus propios escritos: "visiones instantáneas del hombre entre las presencias y las ausencias" (1980: 61; cursivas del autor). El mono gramático no es sino una entre las muchas obras en que Octavio Paz se sitúa poéticamente en el pliegue que se halla entre el lenguaje y el cuerpo, entre la piedra y la flor, entre la vida y el más allá.

\section{BiBLIOGRAFÍA}

Acosta, Juvenal. "Cuerpos violentos. Sexo, amor y muerte en tres poetas mexicanos: Ramón López Velarde, Xavier Villaurrutia y Octavio Paz”. Tesis doctoral (2003) disponible en línea en <www.search.proquest. com>, 3/3/2013.

Areta, Gemma. "Estética y erótica en Octavio Paz", en Coloquio internacional: Escritura y sexualidad en la literatura hispanoamericana. Eds. Alain Sicard y Fernando Moreno. Madrid: Centre de Recherches Latino-Américaines, 1990. 155-165.

Blandin, Noël (ed.). Octavio Paz ou la raison poétique. Entretiens. París: Détours d'écriture, 1991. Número de revista fuera de serie.

Dowson, John. A Classical Dictionary of Hindu Mythology and Religion, Geography, History and Literature. Londres: Routledge \& Kegan Paul, 1961. 
Eggeling, Julius (ed. y trad.). The Satapatha-Brâhmana. 5 volúmenes. Delhi: Eastern Book Linkers, 2009.

Lafaye, Jacques. Octavio Paz en la deriva de la modernidad. México: Fondo de Cultura Económica, 2013.

Paz, Octavio. El laberinto de la soledad. México: Fondo de Cultura Económica, 1959 [2a ed. revisada y aumentada].

Paz, Octavio. Discos visuales. Realización artística de Vicente Rojo. México: Era, 1968.

Paz, Octavio. Conjunciones y disyunciones. México: Joaquín Mortiz, 1969.

Paz, Octavio. Topoemas. México: Era, 1971.

Paz, Octavio. Los hijos del limo: del romanticismo a la vanguardia. Barcelona: Seix Barral, 1974.

Paz, Octavio. "Xavier Villaurrutia en persona y en obra", en Antología de Xavier Villaurrutia. México: Fondo de Cultura Económica, 1980. 9-61.

Paz, Octavio. Posdata. México: Siglo Veintiuno, 1982 [1ª ed. 1970].

Paz, Octavio. La otra voz: Poesía y fin de siglo. Barcelona: Seix Barral, 1990.

Paz, Octavio. La llama doble: Amor y erotismo. Barcelona: Seix Barral, 1993.

Paz, Octavio. El mono gramático. Barcelona: Seix Barral, 1996a [1ª ed. 1974].

Paz, Octavio. Vislumbres de la India. Barcelona: Seix Barral, $1996 \mathrm{~b}$.

Paz, Octavio. "Entre la piedra y la flor", en Obras completas de Octavio Paz, vol. XI, Obra poética I (1935-1970). Ed. del autor. México: Fondo de Cultura Económica, 1997a. 86-92 [1 ${ }^{\text {a }}$ ed. 1937 y 2a ed. revisada 1976].

Paz, Octavio. Ladera este. Obras completas de Octavio Paz, vol. XI, Obra poética I (1935-1970). Ed. del autor. México: Fondo de Cultura Económica, 1997b. 341-390.

Paz, Octavio. "Carta de creencia", en Árbol adentro. Obras completas de Octavio Paz, vol. XII, Obra poética II (1969-1998). Ed. del autor. México: Fondo de Cultura Económica, 2004. 173-181.

Paz, Octavio. El arco y la lira. México: Fondo de Cultura Económica, 2005 [2a ed. corregida y aumentada 1967].

Paz, Octavio y Julián Ríos. Solo a dos voces. Barcelona: Lumen, 1973.

Phillips, Rachel. The Poetic Modes of Octavio Paz. Londres: Oxford University Press, 1972.

Ríos, Julián. "Los caminos de la página: El mono gramático de Octavio Paz", en Álbum de Babel. Barcelona: Muchnik, 1995. 42-47.

Stanton, Anthony. "Octavio Paz como lector crítico de la poesía mexicana moderna", en Nueva Revista de Filología Hispánica 49.1 (2001): 53-79.

Trías, Eugenio. Lógica del límite. Barcelona: Destino, 1991.

VĀlmīki. Rāmāyana. Nueva York: New York University Press, 2006. 
Verani, Hugo J. "Octavio Paz: el poema como caminata", en Octavio Paz: entre poética y politica. Ed. Anthony Stanton. México: El Colegio de México, 2009. 37-68.

Verani, Hugo J. Octavio Paz: el poema como caminata. México: Fondo de Cultura Económica, 2013.

FeCHA DE RECEPCIÓN: 18 de septiembre de 2013

FECHA DE ACEPTACiÓN: 16 de enero de 2014 